\title{
A preliminary investigation into the phytochemicals, vitamins and mineral constituents of the leaf of two tradomedicinal plants - urena lobata and cassia alata used in Nigeria.
}

\author{
Abii T.A and Onuha E.N \\ Department of Chemistry, College of Physical and Applied Sciences, Michael Okpara Univeristry of Agriculture \\ Umudike, Abia State, Nigeria.
}

\begin{abstract}
This paperreports on the chemical constituents and trado medicinal values of ureta lobata and cassia alata leaves which are used locally by tradomedical practioners. The plant leaves were collected from Amoba village in Ikwuano local government area of Abia State Nigeria and analyzed for their phytochemicals, vitamins and mineral elements using appropriate standard methods. The results show that they contain alkaloids, saponins, flavonoids, tannins, phenols and vitamins like ascorbic acid,riboflavin, niacin and thiamin. The major mineral elements include $\mathrm{K}, \mathrm{Na}, \mathrm{Ca}, \mathrm{Mg}$ and $\mathrm{P}$ while the trace metal elements include $\mathrm{Zn}, \mathrm{Cu}, \mathrm{Se}, \mathrm{Ni}, \mathrm{Cd}$ and $P b$. These constituents of these plants were then used to explain and justify the medicinal potentials of these leaves as claimed by tradomedical practioners.
\end{abstract}

Key words:Ureta lobota, cassia alota chemical constituent's tradomedicinal potentials.

\section{Introduction}

Medicinal plants have been used by man for centuries. They are still important especially in many developing communities where traditional remedies are commonly used in the treatment of numerous ailments. A medicinal plant is any plant which in one or more of its parts contains potent chemical compounds that can be used for therapeutic purposes or which are precursors for the synthesis of useful drugs.

Recently, the search for anti-infective agents from natural sources based on their tradomedicinal uses has resulted in many native plants being investigated; [1,2,3,4,5,6,\& 7].

Urena lobata is one of the useful medicinal plants in Nigeria that is used extensively in ethnomedical practices It is an erect, branched shrub of $0.6 \mathrm{~m}$ to $2.5 \mathrm{~m}$ high.It is very variable and more or less hairy. Its stem is often with reddish branches. The leaves are pale beneath, heart shaped at the base, toothed or somewhat lobed or angled,[8]. The flowers are pink or purplish, about $1.7 \mathrm{~mm}$ in diameter and borne singly in the axil of the leaves, [9]. The fruits are rounded, but flattened andabout $7 \mathrm{~mm}$ in diameter with carpels covered with barbed spines, [10].

Different extracts of the leaves were used in herbal medicine to cure diverse ailments. The medicinal potentials of this shrub as claimed by tradomedical practitioners range from the cure of rheumatism, gonorrhea, toothache and wounds to fungal infections (ringworm) expulsion of worms, intestine cleansing. In South Africa it is used for high blood pressure, fever, asthma, syphilis; [11 \& 12].

Cassia alata is a course, erect shrub, about $3.4 \mathrm{~m}$ tall and the flowers are yellow, crowded and overlapping, [13]. The leaves are highly effective against skin diseases and so used to treat ringworm. They are also used as laxative and to expel intestinal parasites. The boiled leaves are used to cure high blood pressure. Gulati et al 2002 have reported the use of this shrub to treat a wide range of ailments from eczema, stomach problems,fever,asthma, snake bite and veneral diseases.

This study tends to investigate the chemical constituents that contribute to the medicinal potentials of urena lobata and cassia alata in an attempt to provide a scientific backing to the claim of their wide application in traditional medicine.

\section{Materials And Methods}

The fresh leaf samples of urena lobata and cassia alata were collected from a village Amaba in Ikwuano Local Government Area of Abia State in Nigeria. The samples were identified at the taxanomy section of the department of forestry,Michael Okpara University of Agriculture Umudike

\section{SAMPLE PREPARATION}

The samples were cleaned and put in an oven at a temperature of $60^{\circ} \mathrm{c}$ for 6 hours. After drying, the leaf samples were ground into a fine powder with electric maulinex blender prior to use for further analysis. The dried powdered materials were stored in air-tight bottles until required for analysis. 


\section{VITAMIN DETERMINATION}

Riboflocin, thiamin, niacin and vitamin A were determined by the method of Scalar Analysers [14] while ascorbic acid content was determined by the method of Barakat et al[15].

\section{PHYTOCHEMICALS DETERMINATION}

Saponins, Tanins, flavonoids, alkaloids and phenols were determined by the method of Hurbron[16]. Oxalate and phytate were analysed by the method of Sofowara[17].

\section{MINERAL COMPOSITION}

After extracting the minerals by the wet acid digestion method, phosphorus was determined by the Vanado molybdate spectrometric method. Ca and $\mathrm{Mg}$ were determined by Versando EDTA complexcometric titration method as modified by James[18]. $\mathrm{K}$ and $\mathrm{Na}$ were determined by flamephotometry.

\section{Phythochemical analysis}

\section{Results And Discussions}

Table 1 shows the results of the phytochemicals analyzed. The leaves of urena lobata and cassia alata contain respectively the following: alkoloids $(8.190 \%$ and $4.360 \%)$; saponins $(3.630 \%$ and $2.410 \%)$; flavonoids $(1.21 \%$ and $0.650 \%)$ : Tannins $(0.112 \%$ and $0.152 \%)$ and phenols $(0.134 \%$ and $0.142 \%)$.

Table 1: Phytochemical constituents of the leaves of cassia alata and urena lobata in \%

\begin{tabular}{|l|l|l|}
\hline Phytochemicals & Urena lobata & Cassta alata \\
\hline Alkoloids & 8.190 & 4.360 \\
\hline Saponins & 3.630 & 2.410 \\
\hline Flavonoids & 1.210 & 0.668 \\
\hline Tannins & 0.112 & 0.152 \\
\hline Phenols & 0.134 & 0.142 \\
\hline
\end{tabular}

These results give justification for the use of these plants in tradomedical practices. The plants are rich in alkoloids and saponins which are known to have antimicrobial activity as well as other physiological activity,[19]. Flavonoids are known for their vast role in biological activities which include protection against allergies, viruses and tumors, ulcers, inflammation and platelets aggregation[20].These flavonoids are potent water-soluble super antioxidants and free radical scavengers which provide protection against oxidative cell damage,[21]. They also provide antioxidative properties against some certain forms of cancer and protect against all stages of carcinogenesis, [22 \& 23].

The presence of phenol in Urena lobata and cassia alota suggests that the plants might be antimicrobial agents as phenolic compounds have been used extensively in disinfectants and remain the standard with which other bactericides are compared,[21]. Phenols have the ability to block specific enzyme that cause inflammation,[24]. The presence of phenols gives the leaves of urena lobata the potent antiseptic bactericidal properties and this supports the use of the leaves extract in rheumatism, gonorrhea treatment and in preventing the formation of infections. The leaves have high sapanin contents. Saponins have the tendency to fight microbes. They are well known for their homeostatic activities because of their characteristic soapy nature,[25]. Hence the high saponin content of cassia alata justifies its antifungal properties and its reported use in the treatment of ringworm, snake bite, veneral diseases [12], and its use in making of soaps and lotions.

Table II shows the vitamin content of the leaves of urenalobata and cassia alata in $\mathrm{mg} / \mathrm{kg}$ respectively as follows: ascorbic acid (II.00 and 8.00), Ruboflavin (0.230 and 0.530). Niacin (2.895 and 2.725). Thiamin (1.280 $\& 1.465)$.

Table 2: Vitamin content of the leaves of urena lobata and cassia alata in $\mathbf{m g} / \mathbf{1 0 0 g}$

\begin{tabular}{|l|l|l|}
\hline Vitamin & Urena lobata & Cassia alata \\
\hline Ascorbic acid & 11.000 & 8.800 \\
\hline Riboflavin & 0.230 & 0.550 \\
\hline Niacin & 2.895 & 2.725 \\
\hline Thiamine & 1.280 & 1.465 \\
\hline
\end{tabular}

These vitamins are essential to the body as their deficiencies negatively affect the body metabolism. Lack of ascorbic acid impairs the normal formation of intercellular substance throughout the body including collagen and bone matrix [26]. One of the pathological changes resulting from the defect of the vitamins is the weakening of the endothelial wall of the capillaries due to reduction in the amount of intercellular substance [27,28 \& 3] 
giving rise to pains in the joints. Vitamins $\mathrm{C}$ is implicated in the synthesis of anti-inflammatory steroids and in wound healing [29].

Thiamine deficiency results in cardiac failure, muscle weakness and gastro-intestinal malfunction [30].

Vitamin $\mathrm{C}$ could therefore account for the antimicrobial activities of the study plants and justifies the antiinflammatory potentials of cassia alata and the use of urena lobata in the treatment of rheumatic pains.

The presence of the vitamins in the plants makes them tools in herbal medicine for the treatment of various ailments.

The results of the major andtrace mineral elements are shown in Table $3(\mathrm{a} \& \mathrm{~b})$. The major mineral element for urena lobata and cassia alata respectively in \% (Table3a) are as follows: 0.250 and 0.475 for Na; 0.444 and 0.303 for $\mathrm{K}, 1.570$ and 1.710 for $\mathrm{Ca} ; 0.766$ and 0.305 for $\mathrm{Mg}, 1.890$ and 1.645 for $\mathrm{N}$. Table 3(b) is the trace mineral elements in $\mathrm{mg} / 100 \mathrm{~g}$ for urena lobata and cassia alata respectively as follows 9.93 and 9.45 for $\mathrm{Ni}$, 37.18 and 34.40 for $\mathrm{Zn}, 7.93$ and 8.80 for $\mathrm{Cu} .0 .20$ and 0.25 for $\mathrm{Cd}$. 9.02 and 8.45 for $\mathrm{Pb}$.

Table 3: Mineral elements of the leaves of ureta labota and cassia alata

\begin{tabular}{|l|l|l|}
\hline (a) Major mineral elements in \% & Ureta lobata & Cassia Alata \\
\hline $\mathrm{K}$ & 0.675 & 0.75 \\
\hline $\mathrm{Na}$ & 0.250 & 0.475 \\
\hline $\mathrm{P}$ & 0.444 & 0.303 \\
\hline $\mathrm{Ca}$ & 1.570 & 1.710 \\
\hline $\mathrm{Mg}$ & 0.760 & 0.305 \\
\hline $\mathrm{N}$ & 1.890 & 1.645 \\
\hline \hline $\begin{array}{l}\mathrm{b} \text { ) Trace mineral elements in } \\
\mathrm{mg} / 100 \mathrm{~g}\end{array}$ & & \\
\hline $\mathrm{Ni}$ & & 9.45 \\
\hline $\mathrm{Zn}$ & 9.93 & 34.40 \\
\hline $\mathrm{Cu}$ & 37.18 & 8.80 \\
\hline $\mathrm{Cd}$ & 7.93 & 0.35 \\
\hline $\mathrm{Ph}$ & 0.20 & 8.45 \\
\hline
\end{tabular}

The results clearly show that the study plants are rich sources of mineral elements that are highly essential for normal body growth and development. The results obtained for sodium and potassium are within the range for the management of hypertension[31]. Phosphorous is necessaryfor energy producing reactions in the cell as well as the structural component of the skeleton,[20].

The major mineral elements have calcium as the most predominant while zinc tops the list of the trace elements.

Caclium and phosphorus are needed for blood coagulation. Deficiency of magnesium causes mouscular cramps, rigidity and spasm. The presence in these plants of calcium, phosphorus and magnesium that form the skeleton makes them useful for those suffering from bone demineralization and justifies the use of these plants to cure rheumatism[7].

Copper is a micronutrient that acts as a biocatalysis. It is required for body pigmentation and in addition to iron, maintains a healthy central nervous system and prevents anemia [32]. Zinc is the most important metal for normal body growth and development in humans. It provides a protective mechanism against virus and its deficiency leads to the weakening of the immune system, diarrhea and mental depression [33].Selenuim is an antioxidant that stimulates the immune system and contributes to the formation of antibodies against infectious agents. Nickel activates some enzyme systems in the body [34].

The presence of these minerals reinforces the medicinal potentials of these study plants.

\section{Conclusion}

The results of the present work on cassia alata and urena lobata show that they are rich in health enhancing phytochemicals, vitamins and minerals. This gives credence to their uses in the management of various ailments by tradomedical practioners. They are potential sources of useful drugs but further work is needed to isolate, characterize and elucidate the bioactive compounds for industrial drug bases.

\section{References}

[1] Ekpe E.D, Ebana R.U.B and Madumagu B.E : Antimicrobial activity of four local medicinal plants on pathogenic bacteria and phyto- pathogenic fungi; W. Afri J. Biol. Appl. Chem.35:2-6. (1990)

[2] Ebana R.U, Essien A.I and Ekpa D.D : Nutritional and potentially medicinal value of the leaves of Lasianthra Africana: Global Journal of pure and Applied science Vol 1:1-8. (1995)

[3] Okwu, D.E and Josiah, C. : Evaluation of the chemical composition of two Nigerian medicinal plants: African Journal of Biotechnology 5 (4) 357-361.(2006)

[4] Okoli, C.O., Akah, P.A and Ezugworie, U.: Anti-Inflammatory activity of extract of root bark of Securidace longitpedunculata Fres (polygalance). Afri.J. Triad .CAM.3, 54-63. (2006)

[5] Sofowara, A. : Medicinal plants and Traditional Medicine in Africa. 2ed: Spectrum Books ltd Ibadan.(1993) 
[6] Abii, T.A and Elegalam Amarachi : Investigation into the chemical composition of the dry fruit of tetrapleura tetraptera: Journal of food Technology 5 (3) 229-232.(2007)

[7] Abii, T.A and Onuoha, E.N.:The chemical constituents of the leaf of Aspilia Africana as a scientific Backing to its Tradomedical potentials. Agricultural journal 6(1):28-30. (2011)

[8] Akhere, A; Omonkhua: The Internet Journal of Nutrition and wellness. Vol 6 (2). (2007)

[9] Yadav, Arun K; Tangpu Vareishang: Pharmaceutical Biology Vol 45, number 3; 223-229. (2007)

[10] Gupta Mazumber, M: Antibacterial activity of urena lobata root: UK, Fitoterapia 72 (8) 927-1929. (2002)

[11] Gulati, K; Debnath P. K. Bhatta charge S.K: Immunomodulatory Indian medicinal plants; journal of Natural Remedies 2:121-131. (2002)

[12] Zannoni V. G and Sato, P.H: Effects of ascorbic acid on microsomal vdrug metabolism; Ann N.Y Acad. 258:119-124. (1975)

[13] Stray, F: The Natural guide to medicinal Herbs and Plants. Tiger Books International London Pp 12-16(1998)

[14] Skalar :Segmented flow analysers for the analytical and process laboratories: Netherlands, pp45, 65, and 61 (2000).

[15] Barakat, M.Z, Shehah S.K, Darwist and Zahermy E.I : Determination of Ascorbic acid from plant. Analyst Boichem.53 225-245 (1993).

[16] Harbrone, J.B: Phytochemical methods: chapman and Hall: London and EW York pp 110-113(1973)

[17] Sofowara A,: Medicinal Plants and Traditional Medicine in Africa. John wiley and Sons Ltd. Pp. 1-10.1982

[18] James C.S,:analytic Chemistry of Foods.Capman and Hall, New York (1995)

[19] Duke, J.: Handwork of Biological Active phytochemicals and their activities. BOCA Raton (FL) CRC Press Pp 99-131(1992)

[20] Harbone, H.E; Nutritional Reviews $5^{\text {th }}$ Ed. The Nutritional Foundation Inc., Washington D.C Pp 418(1984)

[21] Saleh, N. Miller, N.J; Pagange, g; Tijburg, L; Bolwell, G.P; Rice, E. Evans, C.: Polyphenolic Flavonoids as scavenger of aqueous phase radicals as chain braking antioxidants: Arch Biochem. Broph. 2: $339-346(1995)$

[22] Del- Rio, Obdululio. R.G. Castillo, J: Matin, F.G. Ortuno, A. :Uses and properties of citrus flavonoids: J. Agric. Food chemistry 45:4505-4(1997),

[23] Okwu, D.E :Phytochemicals, vitamins and mineral content of two Nigerian medicinal plants. International Journal Molecular Medicine and Advanced Science 1, 375-381(2005)

[24] Hugo, W.B and Russel, A.D :Pharmaceutical microbiology $3^{\text {rd }}$ edition, Blacked scienctific publishing 47. (1983)

[25] Trease, G.E and Evans, W.C: Pharmacognosy, English language Book society, Bailliers, Tindal-Easthoume PP 401.-131. (1983)

[26] Hoen, S.K and Kaufer, J.N: L-.ascorbic acid Lysosomal acid hydrolase activities of guinea pig liver and Brain: J Biochem 56: 353356 (1978)

[27] Hunt, S; Groff, I.L Holbrook, J. :Nutrition, principals and chemical practice: John Eiley and sons New York Pp 49-52, 459 -462 (1980)

[28] Okwu, D.E and Mora, F.N :Mineral and Nutritive value of Dennettia, Tripetala fruits: Fruits: 59: 437-442 (2004)

[29] Bioguist, H.P.: Carotene Biosynthesis and function .Fed. Proc. 41: 2840-2842 (1982)

[30] Tanphaichitr, V and Wood, R. :Nutritional Review $5^{\text {th }}$ ed. The Nutritional Faundation Inc. Washington D.C Pp 277(1982).

[31] Anderson, D., Dibble, M.U, Turkki, P.R., Mitchell, H.S and Ryndbergen, H.J: Nutrition in health and diseases (17 $7^{\text {th }}$ Edn.), J.B Lippioncott Company Philadelphia.(1982)

[32] Akinyele, I.O and Osibanjo, O.: Level of some trace elements in Hospital diet. Food chemistry, Vol. 9, 81-84. (1982)

[33] Strusel, L. and P. Saltman, :Trace Mineral interaction. Department of Biology, University of California, San Diego, CA. USA. (2000).

[34] Divirikli U, Hozam N, Soytak M, Eki L.: trace heavy metal content of some spices and herbal plants from western Antola Turkey: Int J. Food sci technol 41, 712-716.jk (2008) 